\title{
PEMASARAN PRODUK DISTRIBUTOR OUTLET DALAM TINJAUAN ETIKA BISNIS ISLAM
}

\author{
Syafrudin, Ahmad Dasuki Aly, S. dan Teja Subakti \\ Fakultas Syariah dan Ekonomi Islam \\ Institut Agama Islam Negeri Syekh Nurjati Cirebon \\ e-mail: ujangsyaf@gmail.com,abahali_sukses@yahoo.com \\ dantejasubakti@gmail.com
}

\begin{abstract}
This research is in the background because of unhealthy competition and lack of ethics owned by the entrepreneurs distro in Babakan subdistrict in running their business activities. The existence of a competition in the business, one of them by mutual menggelek-ugly fellow business. This is certainly contrary to the business teachings in accordance with the principles of Sharia. The method used in this research is qualitative by using Islamic business ethics approach. Technique of collecting data which is done, that is observation, interview and documentation. From the results of this study indicates that marketing ethics conducted by entrepreneurs distro in sub-district Babakan already in accordance with Islamic Business Ethics. by applying marketing ethics in the context of Production, within the context of Price, in the context of Distribution, and in the context of Promotion. And each context of marketing ethics has been well executed by the perpetrators of business distro in sub-district Babakan in accordance with Islamic Business Ethics.
\end{abstract}

Keywords: Marketing Ethics, Distro, and Islamic Business Ethics

\begin{abstract}
Abstrak
Penelitian ini di latar belakangi oleh adanya persaingan tidak sehat dan kurangnya etika yang dimiliki oleh para pengusaha distro di kecamatan babakan dalam mejalankan aktivitas bisnisnya. Adanya suatu persaingan dalam usaha tersebut, salah satunya dengan saling menjelek-jelekan sesama pelaku bisnis. Hal ini tentunya bertentangan dengan ajaran bisnis yang sesuai dengan prinsip Syariah. Metode yang digunakan dalam penelitian ini adalah kualitatif dengan memanfaatkan pendekatan etika bisnis Islam. Teknik pengumpulan data yang dilakukan, yaitu observasi, wawancara dan dokumentasi. Dari hasil Penelitian ini menunjukkan bahwa etika pemasaran yang dilakukan oleh para pengusaha distro di kecamatan babakan sudah sesuai dengan Etika Bisnis Islam. yaitu dengan menerapkan etika pemasaran dalam konteks Produksi, dalam konteks Harga, dalam konteks Distribusi, dan dalam konteks Promosi. Dan masing-masing konteks etika pemasaran tersebut telah dijalankan dengan baik oleh para pelaku usaha distro di kecamatan babakan sesuai dengan Etika Bisnis Islam.
\end{abstract}

Kata Kunci : Etika Pemasaran, Distro, dan Etika Bisnis Islam. 


\section{PENDAHULUAN}

Islam adalah cara hidup yang seimbang dan koheren, dirancang untuk kebahagiaan (falah) manusia dengan cara menciptakan keharmonisan antara kebutuhan moral dan kebutuhan materil manusia dan aktualisasi keadilan sosio-ekonomi serta persaudaraan dalam masyarakat manusia. Oleh karena itu islam juga mempunyai konsep filosofis dalam mengatur kehidupan sosial ekonominya yang dituangkan dalam konsep ekonomi islam telah mengatur kehidupan seorang muslim dengan ketentuan syariah (hukum islam) yang bersumber pada alQur'an dan Hadits Rasulullah saw tujuannya untuk menegakan keadilan dan kesejahteraan manusia sesuai dengan perintah Allah SWT. ${ }^{1}$

Sistem ekonomi Islam mengutamakan aspek Hukum dan Etika, yakni adanya keharusan menerapkan prinsip-prinsip hukum dan etika bisnis yang Islami, antara lain prinsip ibadah (attauhid), persamaan (al-musssawwat), kebebasan (al-hurriyah), keadilan ( $a l$ - 'adl), tolong-menolong (at-ta'awun), dan toleransi (at-tasamuh). Prinsip-prinsip tersebut merupakan pijakan dasar dalam sistem ekonomi islam, sedangkan etika bisnis mengatur aspek hukum kepemilikan, pengelolaan dan pendistribusian harta, yakni menolak monopoli, eksploitasi, dan diskriminasi serta menuntut keseimbangan antara hak dan kewajiban. ${ }^{2}$ Sejatinya, bisnis yang baik adalah bisnis yang tidak hanya mengejar keuntungan duniawi saja, melainkan juga keuntungan akhirat. Salah satu yang sering dilupakan oleh pelaku bisnis adalah aspek etika dalam berbisnis. ${ }^{3}$

\footnotetext{
${ }^{1}$ Muh. Ahkram Kha, Ajaran Muhammad SAW. tentang Ekonomi: Kumpulan Hadits-hadits Pilihan tentang Ekonomi, (Jakarta: PT. BMI, 1996), 17.

${ }^{2}$ Abdul Aziz, Etika Bisnis Perspektif Islam (Bandung: Alfabeta, 2013), 13-14.

${ }^{3}$ Yusuf Qardhawi, Norma dan Etika Ekonomi Islam (Jakarta: Gema Insani Press, 1993), 31 .
}

Dalam upaya merintis perajutan jaringan, memasarkan produk atau jasa berbeda konsep dan prosesnya dengan menjual produk. Menjual hanya merupakan bagian dari proses pemasaran, dan menjual tidak akan sukses sebelum tinjauan pemasaran dan rencana penjualan dibuat. ${ }^{4}$ Dalam menghadapi persaingan bisnis retail secara global, tak jarang para pelaku bisnis melakukan segala macam cara agar dapat bertahan (survive) di tengah persaingan global saat ini. Beragam kecurangan atau penipuan demi mengejar keuntungan yang besar akan dilakukan oleh perusahaan retail tanpa memperhatikan aspek lainnya.

Kehadiran distro sangatlah lekat dengan gaya hidup anak muda yang cenderung senang berkumpul dan bergabung dengan komunitas-komunitas tertentu sesuai dengan minat atau hobi yang mereka miliki. Ketatnya persaingan pasar dan banyaknya distro baru yang mulai bermunculan, menuntut para pelaku bisnis distro untuk terus berkreasi dan berinovasi untuk memanjakan para konsumennya. Salah satunya saja seperti mengeklaim produknya sebagai produk yang berbeda dengan produk dari perusahaan distro lainnya. Bahkan banyak dari beberapa distro yang memplagiasi brand atau merek dari merek merek ternama. Strategi pemasaran seperti ini belakangan mulai dijalankan para pengusaha yang membuka lapak distro online.

Untuk itu maka penulis merasa perlu untuk mengkaji lebih dalam lagi mengenai 1) Bagaimana Etika Pemasaran Produk Distro di Kecamatan babakan? 2) Bagaimana Tinjauan Etika Bisnis Islam Terhadap Etika Pemasaran Produk Distro di Kecamatan Babakan?

\section{LETERATURE RIVIEW}

Penelitian tentang Etika Pemasaran Produk Distributor Outlet di Tinjau Dalam Etika Bisnis Islam bukanlah suatu yang baru.

${ }^{4}$ Muhammad Ismail Yusanto, Menggagas Bisnis Islami (Jakarta: Gema Insani Press, 2003), 87. 
Meskipun demikian, nampaknya belum ditemukan penelitian yang secara spesifik dikaji dari segi Etika Bisnis Islam. Berikut beberapa karya yang terdokumentasikan terkait permasalahan yang dikaji, yaitu pertama, penelitian yang dilakukan oleh Arie Rachmat Sunjoto. ${ }^{5}$ Alasan utama dalam penelitian ini adalah untuk mengembangkan strategi pemasaran Swalayan Pamella di DIY, tim pemasaran hendaknya perlu mengikuti pelatihan tentang pemasaran, menambah varian barang berlabel halal, membuat slogan tulisan yang mengajarkan nilai-nilai Islam dan menerapkannya dalam perniagaan. Memberikan motivasi kepada tim pemasaran dalam etika perdagangan yang berlaku dalam Islam. Mengangkat Konsultan dalam memutuskan strategi pemasaran. Mengadakan penelitian tentang tingkat kepuasan konsumen Swalayan Pamella. Untuk strategi pemasaran Swalayan Pamella di DIY agar memprioritaskan strategi pengembangan diversifikasi barang, sistem distribusi barang, bekerja sama dengan perbankan Islam dan koperasi pedesaaan.

Kedua, penelitian yang dilakukan oleh Suindrawati. ${ }^{6}$ Penelitian ini memfokuskan untuk mengetahui Strategi pemasaran Islami dalam meningkatkan penjualan pada ditoko jesy busana muslim bapangan mendenrejo blora. Menurutnya, hasil penelitian tersebut menunjukan bahwa ditinjau dari perspektif stratregi pemasaran islami, maka walaupun took jesy busana muslim menerapkan teori dan konsep strategi pemasaran konvensional, namun ternyata menerapkan juga strategi pemasaran islami, kedua etika bisnis islami, ketiga mencontoh praktik pemasaran Nabi Muhammad SAW. Karakteristik

\footnotetext{
${ }^{5}$ Arie Rachmat Sunjoto, "Strategi Pemasaran Swalayan PamelladDalam Perspektif Islam", Jurnal Ekonomi Syariah Indonesia, Vol. 3, No. 1 (2010).

${ }^{6}$ Suindrawati, "Strategi Pemasaran Islami dalam Meningkatkan Penjualan (Studi Kasus di Toko Jesy Busana Muslim Bapangan Mendenrejo Blora)", Skripsi (Semarang: UIN Walisongo, 2015).
}

pemaasaran yang diterapkan took jesy busana muslim adalah ketuhanan (tauhid), akhlak, realistis, humanistis.

Dan ketiga, penelitian yang dilakukan oleh Muhammad Saman. Peneletian ini bertujuan untuk menganalisis persaingan industry PT. Pancanata Centralindo. Persaingan yang sehat harus sesuai dengan etika bisnis yang berlaku. Hasil penelitian memperlihatkan bahwa etika atau perilaku yang ditanamkan PT. Pancanata Centralindo terhadap karyawannya tidak sepenuhnya dilaksanakan, ini terbukti masih ada karyawan yang menjual harga barang berbeda dengan harga yang telah diberlakukan oleh perusahaan. Dan adanya kesenjangan social antara pembeli daalam jumlah besar dengan pembeli dengan jumlah kecil dalam hal fasilitas pelayanan. Barang yang dipesan tidak sesuai dengan yang diinginkan dengan ukuran yang tidak sesuai dan barang yang dipesan lama sampainya dan ada barang yang rusak atau cacat. Adanya ketidakpuasan terhadap harga barang yang disamaratakan untuk semua ukuran.

Dari ketiga topik penelitian yang telah dipaparkan di atas, ternyata belum ada tinjauan secara khusus dan komprehensif tentang etika pemasaran produk distributor outlet di tinjau dalam etika bisnis Islam. Dengan menggunakan pendekatan kualitatif, selain nantinya akan tergambar karakteristik etika pemasaran sesuai dengan etika bisnis Islam, diharapkan penelitian ini juga akan mengungkapkan nuansa pembaharuan pemikiran hukum ekonomi Islam sesuai dengan perkembangan saat ini. Di sinilah letak perbedaan studi ini dengan studi-studi yang telah dilakukan sebelumnya.

\footnotetext{
${ }^{7}$ Muhammad Saman, "Persaingan Industry PT. Pancanata Centralindo (Perspektif Etika bisnis Islam)", Skripsi (Jakarta: UIN Syarif Hidayatullah, 2010).
} 


\section{METODOLOGI PENELITIAN}

Jenis penelitian yang digunakan adalah penelitian lapangan. Penelitian lapangan merupakan penelitian yang dilakukan dalam kehidupan sehari-hari atau kehidupan yang sebenarnya. Ide penting dalam penelitian lapangan ini adalah peneliti berangkat untuk mengadakan pengamatan terhadap suatu fenomena dalam suatu keadaan alamiah. ${ }^{8}$ Pada penelitian lapangan ini peneliti mengamati fenomena yang terjadi dalam etika pemasaran produk distro di kecamatan babakan ditinjau dalam etika bisnis Islam sejak bulan September 2017 sampai dengan Januari 2018 dengan membuat catatan yang ekstensif.

Pendekatan penelitian yang dilakukan dengan menggunakan pendekatan kualitatif adalah pengalaman para peneliti dimana metode ini dapat digunakan untuk menemukan dan memahami apa yang tersembunyi dibalik fenomena yang kadang kala merupakan sesuatu yang sulit untuk di pahami secara memuaskan. ${ }^{9}$

Sumber data yang diperlukan adalah data primer dan data sekunder. Data primer didapatkan melalui wawancara dengan informan diantaranya pemilik usahadistro di kecamatan babakan. Adapun data sekunder yang digunakan di sini yaitu, skripsi, jurnal, dan website yang berkaitan dengan etika pemasaran ditinjau dalam etika bisnis Islam.

Metode pengumpulan data yang digunakan adalah observasi, wawancara dan dokumentasi. Pertama, Metode observasi digunakan oleh seorang peneliti ketika hendak mengetahui secara empiris tentang fenomena objek yang diamati. Observasi adalah panca indra manusia (penglihatan dan pendengaran) diperlukan untuk menangkap gejala yang diamati. Apa yang dicatat dan selanjutnya catatan tersebut

${ }^{8}$ Lexy J. Moleong, Metode Penelitian Kualitatif (Bandung: Remaja Rosdakarya, 2014), 2627.

${ }^{9} \mathrm{Pupu}$ Saeful Rahman, "Penelitian Kualitatif', Equilibrium, Vol. 5, No. 9 (Juni, 2012): $1-8$. dianalisis. ${ }^{10}$ Kedua, Wawancara merupakan teknik yang dilakukan dengan jalan mengadakan komunikasi dengan sumber data melalui dialog (Tanya Jawab) secara lisan. Adapun teknik wawancara yang digunakan oleh peneliti dalam hal ini adalah teknik wawancara tidak terstruktur, bersifat luwes, susunan pertanyaan dan susunan kata-kata dalam setiap pertanyaan dapat di ubah-ubah pada saat wawancara, sesuai dengan kebutuhan dan kondisi pekerjaan atau responden yang telah dihadapi. ${ }^{11}$ Dalam pelaksanaannya, peneliti telah mewawancarai langsung pihak-pihak yang bersangkutan, yakni pihak-pihak Pemilik Perusahaan Distro yang berada di daerah kecamatan Babakan kabupaten Cirebon. Dan Ketiga, dokumentasi adalah mencari data mengenai hal-hal atau variabel yang berupa catatan, transkrip, buku, surat kabar, majalah, prasasti, dan sebagainya. ${ }^{12}$ Maksud dari dokumentasi ini peneliti mencari sumber-sumber data yang lain selain wawancara dan observasi yang berkaitan dengan kajian yang dibahas. Seperti misalnya buku-buku yang relevan, laporan kegiatan, foto-foto, film dokumenter dan data yang relevan.

Penelitian ini menggunakan metode analisis deskriptif. Metode ini merupakan metode analisa data dengan cara menggambarkan keadaan atau status fenomena dengan kata-kata atau kalimat yang dipisah-pisah menurut kategori untuk memperoleh kesimpulan. Dalam hal ini, penelitian yang dilakukan oleh peneliti saat itu adalah memecahkan masalah penelitian serta memberikan deskripsi yang berkaitan dengan objek penelitian. Sebagai langkah penutup adalah pengambilan kesimpulan, yang mana pengambilan kesimpulan itu merupakan akhir proses dari sebuah

\footnotetext{
${ }^{10}$ Lexy J. Moleong, Metodologi Penelitian Kualitatif, 157.

${ }^{11}$ Hadari Nabawi, Metode Penelitian Bidang Sosial (Yogyakarta: Gajah Mada University Press, 1990) 104.

${ }^{12}$ Suharsimi Arikunto, Prosedur Penelitian (Jakarta: PT. Raja Grafindo Persada, 1993), 236.
} 
penelitian, dari pengambilan kesimpulan ini akhirnya akan terjawab pertanyaan yang ada dalam rumusan masalah didalam latar belakang masalah.

\section{KONSEP DASAR}

\section{Pemasaran Menurut Islam}

Secara umum pemasaran Islami adalah strategi bisnis, yang harus memayungi seluruh aktivitas dalam sebuah perusahaan, meliputi seluruh proses, menciptakan, menawarkan, pertukaran nilai, dari seorang produsen, atau satu perusahaan, atau perorangan, yang sesuai dengan ajaran Islam. Pentingnya pasar dalam Islam tidak terlepas dari fungsi pasar sebagai wadah bagi berlangsungnya kegiatan jual beli. ${ }^{13}$ Keberadaan pasar yang terbuka memberikan kesempatan bagi masyarakat untuk ambil bagian dalam menentukan harga, sehingga harga ditentukan oleh kemampuan riil masyarakat dalam mengoptimalisasikan faktor produksi yang ada di dalamnya. ${ }^{14}$ Konsep Islam memahami bahwa pasar dapat berperan efektif dalam kehidupan ekonomi bila prinsip persaingan bebas dapat berlaku secara efektif. ${ }^{15}$

Menurut Hermawan Kartajaya dan Muhammad Syakir Sula pemasaran perspektif ekonomi Islam adalah keseluruhan proses pemasaran yang tidak bertentangan dengan prinsip syariah dan mengandung nilai ibadah. Prinsip yang dimaksud tersebut adalah keadilan, kejujuran, transparasi, etika, dan moralitas. Mannan, Siddiqi dan ahli ekonomi Islam lainnya menekankan pentingnya motif altruisme, dan penekanan akan maslahah dalam kegiatan produksi. Perusahaan tidak hanya mementingkan keuntungan pribadi namun juga memberikan kemaslahatan bagi

\footnotetext{
${ }^{13}$ Sukarno Wibowo dan Dedi Supriadi, Ekonomi Mikro Islam (Bandung: Pustaka Setia, 2013), 201.

${ }^{14}$ Heri Sudarsono, Konsep Ekonomi Islam: Suatu Pengantar (Yogyakarta: UII Press, 2008), 229.

${ }^{15}$ Mustafa Edwin Nasution, et.al., Pengenalan Ekslusif Ekonomi Islam (Jakarta: Prenada Media Group, 2014), 160.
}

masyarakat dengan tidak mengabaikan lingkungan sosialnya. ${ }^{16}$

Pasar syari'ah adalah pasar yang emosional (emotional market) dimana orang tertarik karena alasan keagamaan bukan karena keuntungan financial semata, tidak ada yang bertentangan dengan prinsipprinsip muamalah ia mengandung nilai-nilai ibadah, sebagaimana firman berikut ini:

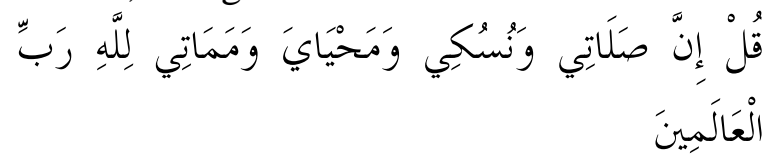

Artinya: Katakanlah, sesungguhnya sembahyangku, ibadahku, hidupku dan matiku hanyalah untuk Allah, Tuhan semesta alam. $^{17}$

M. Syakir Sula mendefinisikan pemasaran syari'ah sebagai sebuah disiplin bisnis strategis yang mengarahkan proses penciptaan, penawaran, dan perubahan values dari satu inisiator kepada stakeholders-nya, yang dalam keseluruhan prosesnya sesuai dengan akad dan prinsipprinsip muamalah dalam Islam. ${ }^{18}$ Dalam dunia pemasaran selalu terkait dengan yang dinamakan marketing mix (bauran pemasaran). Bauran pemasaran dalam perspektif syariah adalah:

a. Produk (product)

Al-Qur'an menggunakan konsep produksi barang dalam arti yang sangat luas. Tekanan al-Qur'an diarahkan pada manfaat dari barang yang diproduksi. Memproduksi suatu barang harus mempunyai hubungan dengan kebutuhan hidup manusia. Di samping itu, Islam mengajarkan untuk memperhatikan kualitas dan keberadaan produk tersebut. Islam melarang jual beli suatu produk yang belum jelas (gharar) bagi pembeli. Islam juga memerintahkan untuk

\footnotetext{
${ }^{16}$ Abdul Aziz, Etika Bisnis Perspektif Islam, $142-143$

${ }^{17}$ QS. Al-An'am (6):162.

${ }^{18}$ Muhammad Aziz Hakim (ed), Dasar \& Strategi Pemasaran Syariah (Jakarta: Renaisan, 2005), 15.
} 
memperhatikan kualitas produk. Barang yang dijual harus terang dan jelas kualitasnya, sehingga pembeli dapat dengan mudah memberi penilaian. Tidak boleh menipu kualitas dengan jalan memperlihatkan yang baik bagian luarnya, dan menyembunyikan yang jelek pada bagian dalam.

b. Harga (price)

Penentuan harga ditentukan oleh mekanisme pasar, yakni bergantung pada kekuatan-kekuatan permintaan dan penawaran. Dalam praktis fiqih muamalah, pricing mengambil posisi tengah, tidak berlebih-lebihan, tidak pula merendah-rendahkan. Ini berarti dalam praktik muamalah, pricing mestinya harus proporsional.

c. Distribusi (place)

Distribusi merupakan semua kegiatan yang dilakukan perusahaan dengan tujuan membuat produk yang dibutuhkan dan dinginkan oleh konsumen dapat dengan mudah diperoleh pada waktu dan tempat yang tepat. Nabi dengan tegas melarang pemotongan jalur distribusi dengan maksud untuk menaikkan harga. Ini bisa dimaknai bahwa jangan pernah membeli dari penjual yang belum mengetahui harga pasar. Hal ini dimaksudkan untuk melindungi penjual dari penipuan mengenai barang yang sebenarnya.

d. Promosi (promotion)

Pada prinsipnya, dalam Islam mempromosikan suatu barang diperbolehkan. Hanya saja dalam berpromosi tersebut mengedepankan faktor kejujuran dan menjauhi penipuan. Di samping itu, metode yang dipakai dalam promosi tidak bertentangan dengan syariah Islam.

Keempat unsur bauran pemasaran suatu produk adalah produk itu sendiri ditambah atribut yang melekat dalam hubungannya dalam pemuasan kebutuhan konsumen, harga yang merupakan kesepakatan penjual dan pembeli agar terjadi pertukaran, sistem pendistribusian, dan promosi untuk menyediakan informasi bagi konsumen. Jadi marketing mix (Bauran Pemasaran) adalah controlable variable yang saling berkaitan satu sama lain, yang disusun dan digunakan oleh perusahaan untuk mencapai pasar sasarannya. ${ }^{19}$

\section{Prinsip Etika Pemasaran Menurut Islam}

Tanpa memperhatikan intensitas persaingan, perusahaan harus bersaing secara etis. Etika pemasaran merujuk pada prinsip atau nilainilai moral secara umum yang mengatur perilaku seseorang atau sekelompok. Standar-standar hukum mungkin tidak selalu etis atau sebaliknya, standar-standar etika belum tentu sesuai dengan standar hukum, karena hukum merupakan nilai-nilai dan standar-standar yang dapat dilaksanakan oleh pengadilan. Etika terdiri dari nilai-nilai dan prinsip-prinsip moral seseorang bukan perintah-perintah sosial. $^{20}$

Dalam kegiatan etika Islami, perlunya landasan moral dalam kegiatan produksi dengan alasan kegiatan produksi tidak hanya bergerak pada ranah ekonomi an sich tapi juga sosial. Selain itu, kegiatan produksi merupakan tanggung jawab sosial untuk memenuhi kebutuhan masyarakat serta manifestasi keterhubungan manusia dengan Tuhan. Prinsip-prinsip etika produksi melainkan hanya menginjeksi aksioma-aksioma moral dalam al-Qur'an sebagai landasan etika kegiatan produksi. ${ }^{21}$

Prinsip-prinsip pemasaran Islami menurut Abdullah Gymnastiar dan Hermawan Kertajaya adalah 1) Berlaku adil, Pada dasarnya kompetitor akan memperbesar pasar, sebab tanpa kompetitor industri tidak dapat berkembang dan kompetitor ini perlu diikuti mana yang bagus dan mana yang jelek, dimana

${ }^{19}$ Suliyanto, Studi Kelayakan Bisnis: Pendekatan Praktis (Yogyakarta: CV. Andi Offset, 2010), 91.

${ }^{20}$ Abdullah Gymnasiar dan Hermawan Kertajaya, Berbisnis Dengan Hati (Jakarta: Mark Plus \& CO, 2004), 46.

${ }^{21}$ Abdul Aziz, Etika Bisnis Perspektif Islam, 148. 
kompetitor yang bagus perlu ditiru. 2) Tanggap terhadap perubahan, Selalu ada perubahan dalam kegiatan perindustrian, sehingga langkah bisnis akan terus berubah untuk menyesuaikan dengan pasar. Kompetisi yang semakin sengit tidak dapat dihindari, arus globalisasi dan teknologi akan membuat pelanggan semakin pintar dan selektif sehingga jika kita tidak sensitif terhadap perubahan maka kita akan kehilangan pelanggan. 3) Berbuat yang terbaik dari sisi produk dan harga, Dalam konsep pemasaran islami, tidak diperbolehkan menjual barang jelek dengan harga yang tinggi, hal ini dikarenakan pemasaran islami adalah pemasaran yang fair dimana harga sesuai dengan barang/produk. 4) Rela sama rela dan adanya hak khiyar pada pembeli (hak pembatalan terhadap transaksi), Pada prinsip ini, marketer yang mendapatkan pelanggan haruslah memelihara hubungan yang baik dengan mereka. Dan dipastikan pelanggan puas terhadap pelayanan yang diberikan, sehingga pelanggan menjadi lebih royal. Dengan arti lain keep the costumer, namun keep the costumer saja tidaklah cukup, perlu pula grow the costumer, yaitu value yang diberikan kepada pelanggan perlu ditingkatkan sehingga dengan bertambahnya pelayanan, pelanggan juga akan mengikuti pertambahan tersebut. 5) Tidak curang, Dalam pemasaran islami tadlis sangatlah dilarang, seperti penipuan menyangkut kuantitas, kualitas, dan waktu penyerahan barang dan harga. 6) Berorientasi pada kualitas, Tugas seorang marketer adalah selalu meningkatkan QCD agar tidak kehilangan pelanggan. QCD yang dimaksud adalah quality, cost, dan delivery. ${ }^{22}$

\section{Produk Menurut Etika Pemasaran Islami}

Produk adalah sesuatu yang dapat ditawarkan kepada pasar untuk mendapat perhatian, dimiliki, digunakan, atau

\footnotetext{
${ }^{22}$ Abdullah Amrin, Asuransi Syari'ah (Jakarta: Media Komputindo, 2006), 200.
}

dikonsumsi, yang meliputi barang secara fisik, jasa, kepribadian, tempat, organisasi, dan gagasan atau buah pikiran. Faktorfaktor yang terkandung dalam suatu produk adalah mutu, kualitas, penampilan (features), pilihan yang ada (options), gaya (style), merek (brand names), pengemasan (packaging), ukuran (sizes), jenis (product lines), macam (produk item), jaminan (warranties), dan pelayanan (service). ${ }^{23}$

Cara mempromosikan produk yang dilakukan oleh pemasar, salah satunya melalui media periklanan, iklan adalah segala bentuk presentasi non pribadi dan promosi gagasan, barang, atau jasa oleh sponsor tertentu yang harus di bayar, Kotler (2005). Pengembangan iklan dipengaruhi oleh lima pengambilan keputusan utama yang terkait dengan Mission (Misi), Money (uang), Media (Media), Message (Pesan), Measurement (ukuran). ${ }^{24}$

Konsep produk pada pemasaran Islami yang dilakukan oleh Nabi Muhammad SAW selalu menjelaskan dengan baik kepada pembeli akan kelebihan dan kekurangan produk yang dijualnya. ${ }^{25}$ Kejujuran adalah kunci utama dalam perniagaan Nabi Muhammad, Kejujuran adalah cara yang termurah walaupun sulit dan langka ditemukan sekarang. Jika kita menjual produk dengan segala kelebihan dan kekuranganya kita ungkapkan secara jelas, maka yakin produk itu akan terjual dan juga akan dipercayai oleh konsumen kita. Dan mereka tidak akan meninggalkan kita karena merasa tidak dibohongi dengan ucapan kita. Berarti menawarkan produk yang terjamin kualitasnya. Produk yang dijual harus sesuai dengan selera serta

${ }^{23}$ Sofjan Assauri, Manajemen Pemasaran Dasar, Konsep dan Strategi, Cet. VII (Jakarta: PT. Raja Grafindo Persada, 2004), 200.

${ }^{24}$ Fify Setyawati dan Fikhy Endriaz, Kode Etik Pemasaran Ditijau dalam Perspektif Marketing Syariah (Bogor: Program Kreativitas Mahasiswa ITB, 2009).

${ }^{25}$ Thorik Gunara dan Utus Hardiono, Marketing Muhammad (Bandung: Madania Prima, 2007), 58. 
memenuhi kebutuhan dan keinginan pelanggan. Muhammad dalam praktik elemen produk selalu menjelaskan kualitas barang yang dijualnya. Kualitas produk yang dipesan oleh pelanggan selalu sesuai dengan barang yang diserahkan. Seandainya terjadi ketidakcocokan, beliau mengajarkan, bahwa pada pelanggan ada hak khiyar, dengan cara membatalkan jual beli, seandainya terdapat segala sesuatu yang tidak cocok.

Kertajaya yang dikutip oleh Bukhari Alma dan Donni Juni Priansa menyatakan bahwa karakteristik pemasaran islami terdiri dari beberapa unsur yaitu ketuhanan, etis, realistis, dan humanistis. Muhammad dalam bukunya "Etika Bisnis Islami" bahwa Etika pemasaran dalam konteks produk meliputi : Produk yang halal dan thoyyib, Produk yang berguna dan dibutuhkan, Produk yang berpotensi ekonomi atau benefit, Produk yang bernilai tambah, Dalam jumlah yang berskala ekonomi dan sosial, Produk yang dapat memuaskan masyarakat. ${ }^{26}$

\section{Etika Bisnis Islam}

Etika bisnis Islam merupakan tuntutan terhadap aktivitas bisnis yang didasarkan atas nilai-nilai yang terkandung dalam alQur'an. Dengan demikian, jika dilihat dari sudut pandang ini, etika bisnis tidak hanya terkait dengan aspek etika secara parsial dan terpisah. Ini berarti bahwa tujuan bisnis tidak semata-mata bersifat materiilkuantitatif, tetapi sekaligus immateriilkualitatif. al-Qur'an tidak memisahkan tujuan materil yang bersifat kuantitatif dari tujuan kualitatif yang bersifat immateriil. Sebaliknya, ia menyatukan tujuan keduanya dalam bingkai etika bisnis, yakni bisnis yang dilandasi oleh kesadaran menjauhkandiri dari praktik-praktik malbisnis yang bersifat destruktif, baik bagi

\footnotetext{
${ }^{26}$ Suindrawati, "Strategi Pemasaran Islami dalam Meningkatkan Penjualan (Studi Kasus di Toko Jesy Busana Muslim Bapangan Mendenrejo Blora), 33-35.
}

pelaku bisnis itu sendiri maupun bagi masyarakat luas.

Etika bisnis dalam al-Qur'an dengan demikian, memosisikan pengertian bisnis sebagai usaha manusia untuk mencari ridho Illahi. Bisnis tidak hanya bertujuan jangka pendek, individual, dan semata-mata keuntungan yang berdasarkan kalkulasi matematis, tetapi juga bertujuan jangka panjang, yaitu tanggung jawab pribadi dan sosial dihadapan masyarakat, negara, dan Allah. Dengan realitas seperti itu, maka menjadi semakin jelas bahwa di dalam Islam tidak ada pemisahan antara etika pada satu sisi dan bisnis pada sisi yang lain. Bisnis berada dalam satu kesatuan bangunan dengan etika. ${ }^{27}$

Allah telah memerintahkan kepada seluruh manusia (bukan hanya untuk orang yang beriman dan muslim saja) untuk mengambil segala sesuatu yang halal dan baik (Thoyib). Selain itu, Allah juga memerintahkan untuk tidak mengikuti langkah-langkah syaitan (dengan mengambil yang tidak halal dan tidak baik). Sebagaimana firman Allah SWT. berikut ini:

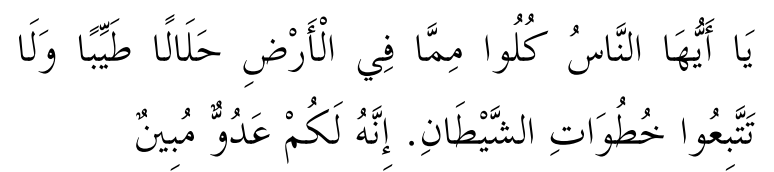

Artinya: Hai sekalian Manusia, makanlah yang halal lagi baik dari apa yang terdapat dibumi, dan janganlah kamu mengikuti langkah-langkah syaitan, karena sesungguhnya syaitan itu adalah musuh yang nyata bagimu. $^{28}$

Rasulullah SAW. memberikan petunjuk mengenai etika bisnis sebagai berikut, ${ }^{29}$ pertama, prinsip esensial dalam

${ }^{27}$ R. Lukman Fauroni, Etika Bisnis dalam al-Qur'an (Yogyakarta: Pustaka Pesantren, 2006), xiv.

${ }^{28}$ QS. Al-Baqarah (2): 168.

${ }^{29}$ Aji Firmansyah, "Analisis Implimentasi Strategi Marketing Mixp pada Manajemen Pemasaran Supermarket Tip Top dari Perspektif Etika Bisnis Islam", Skripsi (Jakarta: UIN Syarif Hidayatullah, 2015) 28-34. 
berbisnis adalah kejujuran. Kejujuran merupakan syarat fundamental dalam kegiatan bisnis, Rasulullah saw sangat intens menganjurkan kejujuran dalam aktivitas bisnis. Rasulullah saw, sendiri selalu bersikap jujur dalam berbisnis. Beliau melarang para pedagang meletakan barang busuk dibagian bawah dan barang baru dibagian atas.

Kedua, kesadaran tentang signifikansi sosial kegiatan bisnis. Pelaku bisnis menurut Islam tidak hanya mengejar keuntungan sebanyak-banyaknya, sebagaimana yang diajarkan Bapak ekonomi Kapitalis, Adam Smith, tetapi juga berorientasi kepada sikap ta'awun (menolong orang lain) sebagai implikasi sosial kegiatan bisnis.

Ketiga, tidak melakukan sumpah palsu. Nabi Muhammad saw sangat intens melarang para pelaku bisnis melakukan sumpah palsu dalam melakukan transaksi bisnis. Praktik sumpah palsu dalam bisnis saat ini sering dilakukaan, karena dapat meyakinkan pembeli, dan pada gilirannya meningkatkan daya beli atau pemasaran. Namun, harus disadari, bahwa meskipun keuntungan yang diperoleh berlimpah, tetapi hasilnya tidak berkah.

Keempat, ramah tamah. Seorang pelaku bisnis harus bersikap ramah dalam melakukan bisnis.

Kelima, tidak boleh berpura-pura menawar dengan harga tinggi, agar orang lain tertarik membeli dengan harga tersebut.

Keenam, tidak boleh menjelekjelekkan bisnis orang lain, agar orang tidak membeli kepadanya.

Ketujuh, tidak melakukan ikhtikar. Ikhtikar adalah menumpuk dan menyimpan barang dalam masa tertentu, dengan tujuan agar suatu saat harganya menjadi naik dan keuntungan besarpun diperoleh.

Kedelapan, bisnis tidak boleh mengganggu kegiatan ibadah kepada Allah SWT.

Kesembilan, tidak monopoli. Salah satu keburukan sistem ekonomi kapitalis ialah melegitimasi monopoli dan oligopoli.
Contoh sederhana adalah eksploitasi (penguasaan) individu tertentu atas hakmilik sosial seperti air, udara beserta tanah dan kandungan isinya seperti barang tambang dan mineral.

Kesepuluh, Tadlis (penipuan). Setiap transaksi dalam Islam harus didasarkan pada prinsip kerelaan antara kedua belah pihak (sama-sama Ridho).

Kesebelas, komoditi bisnis yang dijual adalah barang-barang yang suci dan halal, bukan barang yang haram.

\section{Etika Bisnis dalam Pandangan Hukum Positif}

Undang-undang Nomor 5 Tahun 1999 tentang Larangan Praktek Monopoli dan Persaingan Usaha Tidak Sehat. Dalam UU tersebut, monopoli adalah suatu bentuk penguasaan atas produksi dan atau pemasaran barang dan atau penggunaan jasa tertentu oleh satu pelaku atau satu kelompok pelaku usaha. ${ }^{30}$ Praktek monopoli dan persaingan usaha secara curang merupakan tindakan yang sangat merugikan dunia perbisnisan pada umunya. Oleh karena itu cara-cara seperti itu harus dihilangkan atau setidak-tidaknya harus ditekan agar mempengaruhi kegiatan bisnis pihak lain. Sehubungan dengan itu, pemerintah telah mengeluarkan UU No. 5 tahun 1999 tentang Larangan Praktek Monopoli dan Persaingan Usaha Tidak Sehat. Dalam rangka menegakan peraturan perundang-undangan dalam bidang persaingan usaha, maka diperlukan Lembaga yang bertanggung jawab sebagai pengawas pelaku usaha apabila terjadi praktik-praktik yang melanggar ketentuan dalam UndangUndang. ${ }^{31}$

Dalam pasal 3 UU No. 8 Tahun 1999 tentang Perlindungan Konsumen. Undang-undang tersebut menyebutkan bahwa setiap orang pemakai barang atau

\footnotetext{
${ }^{30}$ Endang Purwaningsih, Hukum Bisnis (Bogor: Ghalia Indonesia, 2010), 90.

${ }^{31}$ Bambang Sutyoso, Penyelesaian Sengketa Bisnis (Yogyakarta: Citra Media, 2006), 216.
} 
jasa yang tersedia dalam masyarakat, baik bagi kepentingan diri sendiri, keluarga, orang lain, maupun makhluk yang lain, dan tidak untuk diperdagangkan, serta hak dan kewajiban konsumen yang tercantum dalam pasal 4 dan 5 UU No. 8 Tahun 1999. ${ }^{32}$

\section{Distributor Outlet}

Distro singkatan dari Distributor Store atau Distributor Outlet adalah jenis toko di Indonesia yang menjual pakaian dan aksesoris yang dititipkan oleh pembuat pakaian, atau diproduksi sendiri. Distro umunya merupakan industri kecil dan menengah (IKM) yang sandang dengan merk independen yang dikembangkan oleh kalangan muda. Produk yang dihasilkan oleh distro diusahakan untuk tidak diproduksi secara massal, agar dapat mempertahankan sifat eksklusif suatu produk dan hasil kerajinan. Secara khusus Distro mendistribusikan produk dari suatu komunitas. Biasanya berasal dari komunitas Band-band independen atau komunitas Skateboard, dan produk yang dijualbelikanpun biasanya hanya ada satu atau dua barang yang sama, yang pasti tidak jauh dari gaya-gaya anak muda dan stylestyle yang mereka sukai.

\section{Perkembangan Distro di Indonesia dan di Kecamatan Babakan}

Distro atau kepanjangan dari Distribution Outlet termasuk ke dalam salah satu jenis industri kreatif fesyen. Pelaku yang terlibat di dalam industri distro pada umumnya adalah anak muda. Anak muda tertarik untuk bergabung ke dalamnya karena diawali dengan rasa ingin mengembangkan kreativitas yang dimiliki. Kreativitas tersebut didasarkan kepada minat (kemampuan individual) untuk memunculkan ide kreatif dalam menciptakan ataupun memodifikasi produk sandang (pakaian) sehari-hari. Produk yang dihasilkan tentunya tidak diproduksi secara

\footnotetext{
${ }^{32}$ Muhammad Djakfar, Hukum Bisnis (Malang: UIN-Malang Press, 2009), 357.
}

massal dan memiliki karakter tersendiri yang bersifat lebih personal (limited edition). Distro pun kemudian dipilih sebagai sebuah wadah (tempat usaha) untuk mendistribusikan sekaligus memperkenalkan hasil-hasil produksi tersebut kepada konsumen.

Distro sudah menjadi sebuah fenomena baru yang hadir di Kota Cirebon khususnya di Kecamatan babakan Kabupaten Cirebon dalam beberapa tahun belakangan ini. Di beberapa titik atau sudut kecamatan Babakan, kita bisa menemui berbagai tampilan distro berdiri megah dan unik sesuai dengan corak, ciri dan karakter yang ditampilkan dari distro itu sendiri. Keberadaan distro menghadirkan gaya busana remaja dan anak muda dengan berbagai macam keunikan dan kelebihannya baik dari ujung kaki sampai ujung kepala bisa kita dapatkan dengan berbagai merek. Melihat isi dari distro sama halnya dengan kita melihat perkembangan gaya busana remaja yang sedang populer saat ini, karena apa yang dilihat dan disediakan dalam pajangan distro, merupakan trend mode yang tengah disukai dikalangan anak muda. Inilah sebuah fenomena yang secara tidak sadar ikut meramaikan berbagai macam perubahan yang ada di Kecamatan Babakan Kabupaten Cirebon.

\section{PEMBAHASAN DAN DISKUSI}

\section{Etika Pemasaran Produk Distro di Kecamatan Babakan}

Berdasarkan hasil penelitian yang dilakukan oleh penulis kepada ketiga pengusaha distro di kecamatan babakan, bahwa dalam melakukan kegiatan bisnisnya, dari ketiga pengusaha Distro di kecamatan babakan telah melakukan berbagai macam cara pemasaran agar produk yang dipasarkan dapat diminati oleh para konsumen.

Berikut merupakan etika pemasaran produk Distro di kecamatan babakan dalam memasarkan produknya, antara lain:

Pertama, Produksi. Dari ketiga pengusaha Distro yang berada di kecamatan babakan. Pada umumnya mereka telah 
melakukan berbagai macam pemasaran dalam jenis apapun, termasuk melakukan inovasi disetiap pemasaran produkproduknya agar dapat mengikuti perkembangan zaman saat ini. Atau memproduksi brand-brand sendiri agar dapat menjadi ciri khas bagi setiap distronya masing-masing.

Kedua, Harga. Dari ketiga pengusaha distro di kecamatan babakan telah berupaya untuk selalu berbuat yang terbaik baik itu dalam segi penjualan produknya atau dalam segi harganya. Artinya selalu berusaha untuk selalu menjual produk-produk yang baik dan berkualitas dan dapat memberikan harga yang terjangkau, dan tentunya tidak berupaya untuk memainkan harga seperti menaikan harga terlebih dahulu disaat ingin memberikan diskon kepada para pembeli.

Ketiga, Distribusi. Dalam konsep Distribusi dari ketiga responden yang telah diteliti oleh penulis telah berupaya untuk dapat mendistribusikan produknya tersebut sesuai dengan apa yang diminta oleh para pembeli. Dan dalam hal ini pula para pelaku usaha distro di kecamatan babakan telah berupaya untuk dapat menciptakan produk yang mereka produksi sendiri agar dapat diminati oleh para pelanggannya.

Dan keempat, Promosi. Dalam konteks promosi ini biasanya dilakukan oleh para pengusaha distro di kecamatan babakan pada saat menjelang lebaran, karena di saat itulah biasanya banyak pembeli yang akan berdatangan.

\section{Tinjauan Etika Bisnis Islam terhadap Etika Pemasaran Produk Distro di Kecamatan Babakan}

Berdasarkan penerapan etika pemasaran produk distro di kecamatan babakan maka dalamhal ini penulis mencoba meninjaunya dalam etika bisnis Islam. Pertama, Produksi. pada dasarnya setiap pengusaha distro di kecamatan babakan telah melakukan perbuatan yang baik dalam segi produksi, yaitu dengan berusaha untuk selalu menjual produk yang asli dan berkualitas. Namun didalam penerapan etika pemasaran dalam memasarkan produknya tersebut dari ketiga pengusaha distro di kecamatan babakan masih ada yang melakukan tindakan saling menjelek-jelekan sesama pelaku usaha distro lainnya, yaitu saudara Zeni. Dalam hal ini tentunya bertentangan dengan Etika bisnis Islam. Dalam hal ini penulis menyimpulkan bahwa meskipun para pelaku usaha distro di kecamatan babakan telah mencoba memasarkan produk-produknya sesuai dengan Etika Bisnis Islam, artinya selalu berusaha untuk memproduksi produkproduknya yang berkualitas dan asli.

Namun berdasarkan penelitian yang dilakukan penulis, penulis menemukan dalam penerapan etika pemasaran dalam segi produksi masih ada dari ketiga pengusaha distro tersebut yang belum sesuai dengan etika bisnis islam. Karena masih ada dari salah satu pengusaha distro di kecamatan babakan yang masih menjelekjelekan terhadap sesama pengusaha distro lainnya. Sebagaimana Nabi berkata di dalam Haditsnya bahwa:

Artinya: Sesungguhnya sebaik-baik penghasilan ialah penghasilan para pedagang yang mana apabila berbicara tidak bohong, apabila diberi amanah tidak khianat, apabila berjanji tidak mengingkarinya, apabila membeli tidak mencela, apabila menjual tidak berlebihan (dalam menaikkan harga), apabila berhutang tidak menunda-nunda pelunasan dan apabila menagih hutang tidak memperberat orang yang sedang kesulitan. $^{33}$

Kedua, Harga. Etika pemasaran produk distro di kecamatan babakan dalam konsep harga sudah sesuai dengan etika bisnis Islam. Yaitu dengan berlaku adil dalam menetapkan konsep harga kepada pembeli dan tidak mencoba untuk

${ }^{33}$ Hadits ini diriwayatkan oleh Al-Baihaqi di dalam Syu'abul Iman, Bab Hifzhu Al-Lisan IV/221. 
memainkan harga pada kualitas produk yang mereka pasarkan tersebut. Dan dalam hal ini pula di pertegas dalam sebuah hadis diriwayatkan oleh Tirmidzi yang berbunyi:

$$
\begin{aligned}
& \text { التاجر الصدوق الأمين مع النبين والصديقين } \\
& \text { و الشهداء }
\end{aligned}
$$

Artinya: Dari Abu Sa'id Radhiyallahu Anhu, Rasalullah SAW berabda, pedagang yang benar dan terpercaya bergabung dengan para nabi, orang-orng benar (shidiqin), dan para syuhada.

Ketiga, Distribusi. Pada dasarnya etika pemasaran dalam konsep distribusi yang dilakukan oleh para pelaku usaha distro di kecamatan babakan sudah berdasarkan etika bisnis Islam. Dalam hal ini para pelaku usaha distro di kecamatan babakan dituntut untuk tetap menjalankan segala aktivitas bisnisnya tersebut dengan berpegang kepada nilai-nilai kebaikan dalam menjalankan segala aktivitas bisnisnya. Dalam konsep distribusi penulis menyimpulkan bahwa dari ketiga pengusaha distro yang berada di kecamatan babakan telah melakukan kegiatan distribusi sesuai dengan Etika Bisnis Islam. Hal ini sebagaimana yang sudah di jelaskan di atas bahwa masing-masing dari ketiga pengusaha distro tersebut telah mengupayakan bersikap melayani dengan baik dalam menjalankan kegiatan distribusinya tersebut terhadap para pembeli.

Rasulullah bersabda bahwa ciri orang yang beriman adalah bermurah hati dengan orang lain, dan berikut adalah Hadits Rasulullah yang diriwayatkan oleh atThabrani:

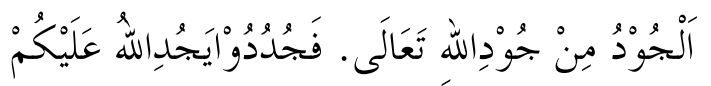

Artinya: Kemurahan hati adalah dari (harta) kemurahan hati dan pemberian Allah. Bermurah hatilah niscaya Allah bermurah hati kepadamu.
Dan keempat, Promosi. Dalam melakukan etika pemasaran dalam konteks promosi para pengusaha distro di kecamatan babakan telah menerapkan etika pemasaran Islami yaitu selalu berusaha melakukan kegiatan promosi dengan benar dan tentunya tidak bertentangan dengan etika bisnis Islam. Para pengusaha distro di kecamatan babakan selalu berupaya untuk berbuat jujur dalam melakukan kegiatan promosinya, artinya dengan tidak berbuat curang mengelabui pembeli dengan memberikan permainan harga. Prinsip terpenting yang mengatur seluruh aktivitas ekonomi adalah keadilan, yang berarti perdagangan jujur dengan sesama dan menjaga keseimbangan keadilan menjaga langit dan bumi berada dalam tempat yang tepatnya masing-masing dan menjadi kekuatan penyatu antara ebrbagai segmen dalam sebuah masyarakat.

Firman Allah swt, dalam Surah AlMaidah menyatakan:

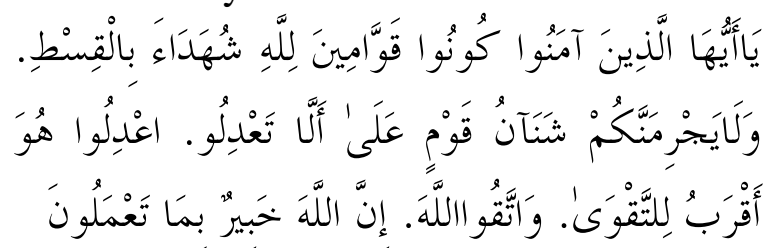

Artinya: Hai orang-orang yang beriman hendaklah kamu jadi orang-orang yang selalu menegakkan (kebenaran) karena Allah, menjadi saksi dengan adil. Dan janganlah sekali-kali kebencianmu terhadap sesuatu kaum, mendorong kamu untuk berlaku tidak adil. Berlaku adillah, karena adil itu lebih dekat kepada takwa. Dan bertakwalah kepada Allah, sesungguhnya Allah Maha Mengetahui apa yang kamu kerjakan. $^{34}$

Oleh sebab itu maka penulis menyimpulkan bahwa etika pemasaran dalam konteks promosi yang dilakukan oleh para pengusaha distro di kecamatan babakan sudah sesuai dengan Etika Bisnis Islam.

\footnotetext{
${ }^{34}$ QS. Al-Maidah (5): 8.
} 


\section{KESUMPULAN}

Berdasarkan pembahasan yang telah penulis sampaikan, dan setelah mengadakan penelitian maka penulis dapat menarik kesimpulan sebagai berikut: Pertama, Etika Pemasaran produk distro yang dilakukan oleh para pengusaha distro di kecamatan babakan pada dasarnya telah berupaya untuk dapat menjalankan kegiatan etika pemasarannya tersebut dengan baik dan benar. Diantara etika pemasaran produk distro yang dilakukan yaitu dengan menerapkan etika pemasaran dalam konteks Produksi, kemudian dalam konteks Harga, kemudian dalam konteks Distribusi, dan dalam konteks Promosi.

Kedua, Tinjauan etika bisnis Islam terhadap etika pemasaran produk distro di kecamatan babakan sudah sesuai berdasarkan etika bisnis Islam. yaitu dengan menerapkan etika pemasaran dalam konteks Produksi selalu berusaha memasarkan produk yang asli dan berkualitas, dalam konteks Harga para pengusaha distro di kecamatan babakan pun tidak berupaya untuk memainkan harga, dalam konteks Distribusi para pelaku usaha distro di kecamatan babakan telah berupaya untuk melakukan kegiatan distribusinya selalu mengedepankan pelayanan yang baik dan berkualitas, dan dalam konteks Promosi para pengusaha distro di kecamatan babakan selalu berupaya untuk dapat menjalankan kegiatan promosinya dengan benar dan tidak berupaya untuk mengelabui pembeli dengan memainkan harga. Dalam hal ini tentunya penulis menyimpulkan bahwa tinjauan etika pemasaran produk distro di kecamatan babakan sudah sesuai dengan etika bisnis Islam.

\section{DAFTAR PUSTAKA}

Amrin, Abdullah. Asuransi Syari'ah. Jakarta: Media Komputindo, 2006.

Arikunto, Suharsimi. Prosedur Penelitian. Jakarta: PT. Raja Grafindo Persada, 1993.

Assauri, Sofjan. Manajemen Pemasaran Dasar, Konsep dan Strategi, Cet. VII. Jakarta: PT. Raja Grafindo Persada, 2004.

Aziz, Abdul. Etika Bisnis Perspektif Islam. Bandung: Alfabeta, 2013.

Djakfar, Muhammad. Hukum Bisnis. Malang: UIN-Malang Press, 2009.

Fauroni, R. Lukman. Etika Bisnis dalam alQur'an. Yogyakarta: Pustaka Pesantren, 2006.

Firmansyah, Aji. "Analisis Implimentasi Strategi Marketing Mix pada Manajemen Pemasaran Supermarket Tip Top dari Perspektif Etika Bisnis Islam", Skripsi. Jakarta: UIN Syarif Hidayatullah, 2015.

Gunara, Thorik dan Utus Hardiono. Marketing Muhammad. Bandung: Madania Prima, 2007.

Gymnasiar, Abdullah dan Hermawan Kertajaya. Berbisnis Dengan Hati. Jakarta: Mark Plus \& CO, 2004.

Hakim, Muhammad Aziz, (ed). Dasar \& Strategi Pemasaran Syariah. Jakarta: Renaisan, 2005.

Kha, Muh. Ahkram. Ajaran Muhammad SAW. tentang Ekonomi: Kumpulan Hadits-hadits Pilihan tentang Ekonomi. Jakarta: PT. BMI, 1996.

Moleong, Lexy J. Metode Penelitian Kualitatif. Bandung: Remaja Rosdakarya, 2014.

Nabawi, Hadari. Metode Penelitian Bidang Sosial. Yogyakarta: Gajah Mada University Press, 1990.

Nasution, Mustafa Edwin, et.al. Pengenalan Ekslusif Ekonomi Islam. Jakarta: Prenada Media Group, 2014.

Purwaningsih, Endang. Hukum Bisnis. Bogor: Ghalia Indonesia, 2010. 
Qardhawi, Yusuf. Norma dan Etika Ekonomi Islam. Jakarta: Gema Insani Press, 1993.

Rahman, Pupu Saeful. "Penelitian Kualitatif”, Equilibrium, Vol. 5, No. 9 (Juni, 2012).

Saman, Muhammad. "Persaingan Industry PT. Pancanata Centralindo (Perspektif Etika bisnis Islam)", Skripsi. Jakarta: UIN Syarif Hidayatullah, 2010.

Setyawati, Fify dan Fikhy Endriaz. Kode Etik Pemasaran Ditijau dalam Perspektif Marketing Syariah. Bogor: Program Kreativitas Mahasiswa ITB, 2009.

Sudarsono, Heri. Konsep Ekonomi Islam: Suatu Pengantar. Yogyakarta: UII Press, 2008.

Suindrawati, "Strategi Pemasaran Islami dalam Meningkatkan Penjualan (Studi Kasus di Toko Jesy Busana Muslim Bapangan Mendenrejo Blora)", Skripsi. Semarang: UIN Walisongo, 2015.

Suliyanto. Studi Kelayakan Bisnis: Pendekatan Praktis. Yogyakarta: CV. Andi Offset, 2010.

Sunjoto, Arie Rachmat. "Strategi Pemasaran Swalayan PamelladDalam Perspektif Islam", Jurnal Ekonomi Syariah Indonesia, Vol. 3, No. 1 (2010).

Sutyoso, Bambang. Penyelesaian Sengketa Bisnis. Yogyakarta: Citra Media, 2006.

Wibowo, Sukarno dan Dedi Supriadi, Ekonomi Mikro Islam. Bandung: Pustaka Setia, 2013.

Yusanto, Muhammad Ismail. Menggagas Bisnis Islami. Jakarta: Gema Insani Press, 2003. 